\title{
Optimization of Rolling-Circle Amplified Protein Microarrays for Multiplexed Protein Profiling
}

\author{
Weiping Shao, ${ }^{1 *}$ Zhimin Zhou, ${ }^{1}$ Isabelle Laroche, ${ }^{1}$ Hong Lu, ${ }^{1}$ Qiuling \\ Zong, ${ }^{1}$ Dhavalkumar D. Patel, ${ }^{2}$ Stephen Kingsmore, ${ }^{1}$ and Steven P. Piccoli ${ }^{1}$ \\ ${ }^{1}$ Molecular Staging, Inc, Suite 701, 300 George Street, New Haven, CT 06511, USA \\ ${ }^{2}$ Thurston Arthritis Research Center, Department of Medicine, University of North Carolina at Chapel Hill, \\ CB\# 7280, 3330 Thurston Building, Chapel Hill, NC 27599-7280, USA
}

Received 13 August 2002; accepted 10 December 2002

\begin{abstract}
Protein microarray-based approaches are increasingly being used in research and clinical applications to either profile the expression of proteins or screen molecular interactions. The development of high-throughput, sensitive, convenient, and cost-effective formats for detecting proteins is a necessity for the effective advancement of understanding disease processes. In this paper, we describe the generation of highly multiplexed, antibody-based, specific, and sensitive protein microarrays coupled with rolling-circle signal amplification (RCA) technology. A total of 150 cytokines were simultaneously detected in an RCA sandwich immunoassay format. Greater than half of these proteins have detection sensitivities in the $\mathrm{pg} / \mathrm{mL}$ range. The validation of antibody microarray with human serum indicated that RCA-based protein microarrays are a powerful tool for high-throughput analysis of protein expression and molecular diagnostics.
\end{abstract}

\section{INTRODUCTION}

Despite great advancements in genomics research, DNA microarrays are still of limited applicability as diagnostic tests, in part because proteins, not genes, are the ultimate effectors of a biological process. Proteins are often expressed at concentrations and varied structural forms having modifications that cannot be predicted from mRNA analysis. There is a great deal of interest in proteomics-based approaches that enable profiling the abundance of proteins, or investigation of proteinprotein and protein-drug interactions. The concept of a protein microarray or biochip is attractive for rapid, highthroughput proteomics studies that utilize available sample volumes $[1,2,3,4]$. Proteins that are present in abnormal concentrations (increased or decreased) in a disease state could be identified and validated as disease markers. Proteomics pattern analysis based on a multiplexed list of biomarkers may well make possible the diagnosis of certain diseases that do not have either effective screening options or biomarkers already detected by conventional immunoassays [5]. Identification of such disease markers will provide valuable information for detection, classification, and prognosis of diseases, as well as targets for treatment outcomes. High-throughput protein chips require arraying a wide range of probes that specifically recognize a single protein in complex mixtures such as serum, plasma, and other biological specimens. These probes are most frequently antibodies or antibody mimics $[3,4,6,7]$.
Given the immense promise of proteomics technologies, there are still limitations that need to be overcome, such as lack of sensitivity and enhanced information about the target. Because there is no PCR equivalent available to amplify proteins, the identification of lowabundance proteins may often be difficult or impossible, and important biomarker information could thus be lost. Rolling-circle amplification (RCA) is a unique signal amplification technology [8] that permits detection of multiple proteins with a broad dynamic range on protein microarrays $[4,9]$. In this paper, we describe the development of RCA-based highly multiplexed and sensitive protein microarray immunoassays for detecting 150 proteins in an ELISA format. Application to human serum and plasma samples has established that the rolling-circle amplified protein microarray is a powerful tool for the profiling of expressed proteins in biological specimens.

\section{MATERIAL AND METHODS}

Preparation of microarrays. Glass slides were prepared and silanized according to procedures previously described [10]. Antibodies (R\&D Systems, Minneapolis, Minn; Pharmingen, San Diego, Calif; BioSource International, Camarillo, Calif) were diluted to $0.5 \mathrm{mg} / \mathrm{mL}$ in PBS containing $0.05 \mathrm{mg} / \mathrm{mL}$ BSA, and $375 \mathrm{pL}$ of each was spotted in quadruplicate onto the slides using a BioChip Arrayer (Packard BioSciences, Downers Grove, Ill). Each spot has a diameter of approximately $180 \mu \mathrm{m}$ with a 
center-to-center spacing of $270 \mu \mathrm{m}$. Each slide was divided by a teflon mask into 16 subarrays, each with a diameter of $0.65 \mathrm{~cm}$. Within each subarray, 256 spots were printed at known locations, containing 40 different features (antibodies for specific antigens) in quadruplicate (160 spots). The remaining features comprised of controls for antibody immobilization, Cy5-labeled mouse IgG and internal calibrators (biotin mouse IgG).

RCA microarray immunoassays. Slides were blocked by adding $30 \mu \mathrm{L}$ blocking buffer $(0.5 \%$ nonfat dry milk, $0.2 \%$ BSA, and $0.05 \%$ Tween-20 in PBS) to each subarray and incubating for 1 hour at $37^{\circ} \mathrm{C}$ in a humidified chamber, and then washed by immersion in PBS containing $0.5 \%$ Brij 35 for 2 minutes. A $15 \mu \mathrm{L}$ aliquot of sample (single analyte or mixture of multiple analytes; serum, plasma, or culture supernatant) was immediately added to each subarray, incubated for 30 minutes at $37^{\circ} \mathrm{C}$, and then washed as described above. After analytes were captured, a $20 \mu \mathrm{L}$ aliquot of the appropriate mixture of biotinylated detection antibodies at $0.1 \mu \mathrm{g} / \mathrm{mL}$ each was applied to individual arrays and incubated at $37^{\circ} \mathrm{C}$ for 30 minutes in a humidified chamber. Slides were washed twice for two minutes in PBS containing $0.5 \%$ Brij 35. A mouse monoclonal antibiotin antibody-primer conjugate was prepared by derivatization of a mouse monoclonal antibiotin IgG (Jackson ImmunoResearch Laboratories, Inc, West Grove, $\mathrm{Pa}$ ) with a 5'-terminal amine-modified oligonucleotide primer, 5'-Thiol-AAA AAA AAA AAA AAA CAC AGC TGA GGA TAG GAC AT-3', as previously described [9]. The conjugate was annealed with $75 \mathrm{nM}$ circle 1 (cyclic 5'-CTC AGC TGT GTA ACA ACA TGA AGA TTG TAG GTC AGA ACT CAC CTG TTA GAA ACT GTG AAG ATC GCT TAT TAT GTC CTA TC-3') in PBS containing $0.05 \%$ Tween-20 and $1 \mathrm{mM}$ EDTA at $37^{\circ} \mathrm{C}$ for 30 minutes. Twenty microliters of the conjugate-circle mixture was applied to each array. Slides were incubated at $37^{\circ} \mathrm{C}$ for 30 minutes and then washed twice. RCA reaction mixture $(20 \mu \mathrm{L})$ containing native T7 DNA polymerase $(20 \mathrm{U} / \mathrm{mL}), 1 \mathrm{mM}$ dNTPs, ssDNA-binding protein $22 \mu \mathrm{g} / \mathrm{mL}, 1 \mathrm{x}$ sequenase buffer, $8 \%$ DMSO, and $0.05 \mathrm{mM}$ Cy5 decorator (5'-Cy5-TGT CCT ATC CTC AGC TGGCy5) was added to each subarray. Slides were incubated at $37^{\circ} \mathrm{C}$ for 45 minutes, then washed twice in PBS containing $0.5 \%$ Brij 35 and once in PBS, and spin-dried. Arrays were analyzed on an Axon GenePix 4000B scanner (Axon Instruments Inc, Foster City, Calif), and fluorescence quantitated by using GenePix Pro 3.0 quantitation software. Data was analyzed by using MSI Analyzer software (Molecular Staging, Inc).

\section{RESULTS AND DISCUSSION}

\section{Fabrication of antibody microarray}

Microarrays were printed on cyanosilane-coated glass slides. This surface was chosen based on experiments indicating that cyanosilane-activated slides have the advantages of (1) simpler preparation, (2) less-expensive

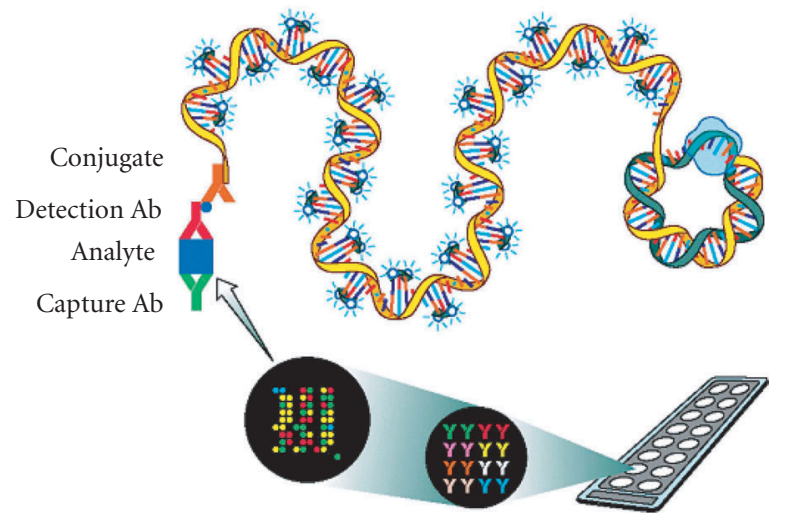

FIgURE 1. Schematic representation of microarray immunoassay with RCA signal amplification. It consists of (a) analyte capture by antibody immobilized on microarray, (b) detection by biotinylated secondary antibody, (c) binding of antibiotin antibody-oligonucleotide conjugate pre-annealed with circle 1 , and (d) rolling-circle replication to generate long single-strand DNA which is hybridized with oligonucleotide decorator.

reagents, and (3) more uniformity of bound antibody spot morphology over thiolsilane-coated and cross-linker (such as GMBS) activated glass slides (data not shown). The concentration of capture antibody for printing was optimized by comparing specific signal intensities from the same capture antibody printed on the chip at different concentrations chosen for microarray printing. Specific signals at $0.5 \mathrm{mg} / \mathrm{mL}$ reached the point of saturation (data not shown), indicating that antibodies saturated the area available for immobilization in the spot. The uniformity of antibody immobilization on the chip was assessed by measuring the coefficient of variation $(\mathrm{CV})$ from the quadruplicate spots using Cy5-labeled anti-isotype antibodies (against the species used in the capture antibodies), previously reported as approximately $10 \%$ for each feature on the chip[4].

\section{Improving the sensitivity of protein detection on antibody array}

Rolling circle amplification enables amplification of signals tethered to proteins and nucleic acids $[4,9,11]$. Immunoassays incorporating RCA have shown a large increase in sensitivity when compared with the direct assay [4]. The technique consists of protein capture by antibody immobilized on microarrays, detection by biotinlabeled second antibody specific for the captured protein, binding of a universal antibiotin antibody oligonucleotide conjugate pre-annealed with circle, and RCA signal amplification where a long single-strand DNA is generated by rolling-circle replication in the presence of DNA polymerase and nucleotides, with hybridization of the RCA product to fluorescent-labeled complementary oligonucleotide probes occurring simultaneously (Figure 1). Besides the signal amplification by RCA, the sensitivity of the antibody array was further improved by two 


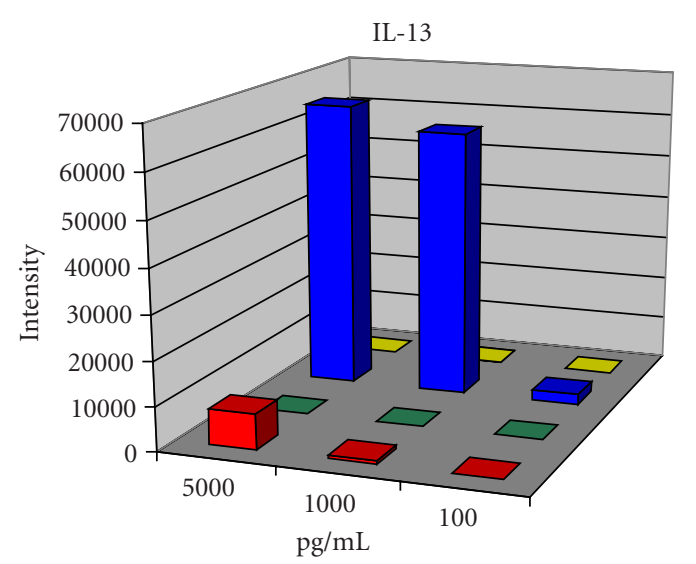

$\mathrm{A}(\mathrm{Cap}) / \mathrm{B}(\mathrm{Det})$

$\mathrm{B}(\mathrm{Cap}) / \mathrm{B}(\mathrm{Det})$

(a)

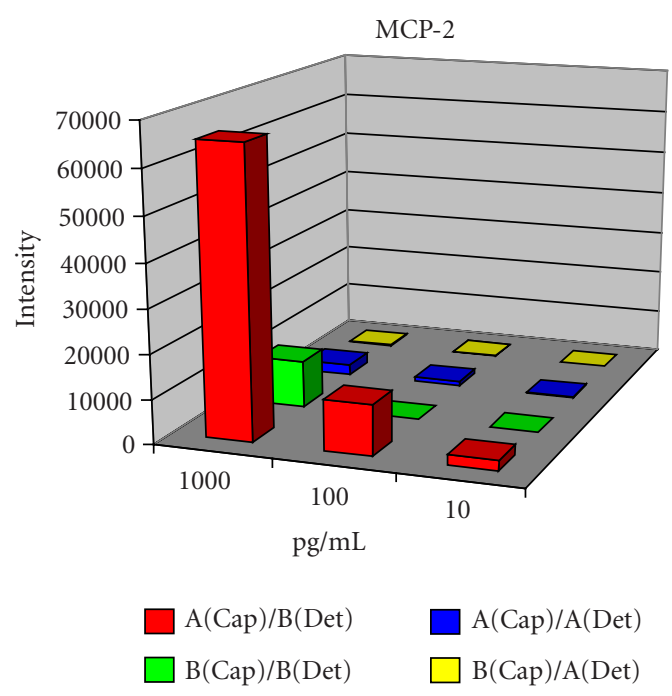

(b)

Figure 2. Optimization of antibodies from different sources (A and B) for choosing optimal pair for immunoassay on protein microarray with examples of (a) IL-13 and (b) MCP-2.

approaches: (1) choosing optimal capture and detection antibody pairs for the microarray immunoassay and (2) optimizing assay procedures.

Antibody microarray development commenced with selection of optimal antibody pairs. For individual features, if the matched antibody pair developed for conventional ELISA was available, it was preferentially selected for the chip development. However, in terms of sensitivity and specificity, antibody pairs do not always function equivalently on plastic ELISA plates and the glassbased microarrays. Antibody pairs from different manufacturers for the same antigen with similar sensitivity as ELISA assays perform quite differently in microarrays.

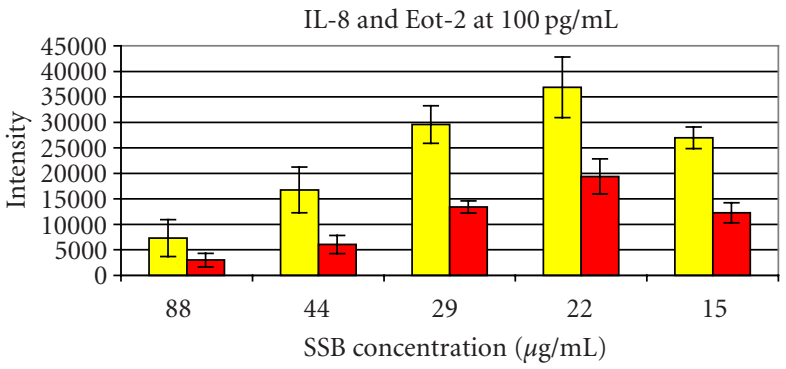

$\square$ IL-8

$\square$ Eot-2

FIgUre 3. Titration of SSB in the RCA reaction mixtures. Cytokine IL- 8 and Eot-2 at $100 \mathrm{pg} / \mathrm{mL}$ were detected.

Thus it has become necessary to select optimal pairs for antibody microarrays by comparing all available antibodies and pairs. As an example, Figure 2a shows the difference between two matched pairs of antibodies (for ELISA) from different sources with specificity for detecting the cytokine IL-13 using the antibody microarray. The pair from source A showed strong signal intensity with a sensitivity of less than $100 \mathrm{pg} / \mathrm{mL}$. However, the pair from source B did not show signal even at concentrations as high as $5 \mathrm{ng} / \mathrm{mL}$ IL-13. Selecting the antibody pair from source A provided at least 50-fold increase of sensitivity when compared with the pair from source B. Alternatively, the ELISA antibody pair from the same set is not always the optimal for a microarray immunoassay. One example shown in Figure $2 \mathrm{~b}$ is for the chemokine MCP2. Neither of the ELISA-matched pairs showed sensitivity better than $100 \mathrm{pg} / \mathrm{mL}$ on the microarray slides. However, using a capture antibody from $\mathrm{A}$ and a detection antibody from B, the sensitivity for MCP-2 was improved to $10 \mathrm{pg} / \mathrm{mL}$ or better, a 10 -fold increase in sensitivity relative to a single manufacturer's reagents. For features without matched pairs, monoclonal antibodies with different binding epitopes or polyclonal antibodies were extensively evaluated for sensitivity ranges permitting detection of biologically relevant changes in protein expression. Cross-reactivity and nonspecific signals were also extensively evaluated as described below.

The second approach of improving sensitivity was to optimize the assay procedures. This involved optimizing detection antibody concentrations, conjugate and circle concentrations, incubation temperatures and time, and RCA reaction solution composition. Analogous to sandwich ELISA assays, the conditions giving the best signal to noise ratio were found to be $0.1 \mu \mathrm{g} / \mathrm{mL}$ of detector with assay incubation time of 30 minutes at $37^{\circ} \mathrm{C}$. Titration of conjugate and circle pre-annealed to conjugate revealed the optimal concentration to be $2 \mu \mathrm{g} / \mathrm{mL}$ conjugate with $75 \mathrm{nM}$ circle. Other components, such as the concentration of single-strand DNA binding protein (SSB), were also optimized for maximum sensitivity in RCA reaction mixtures (Figure 3). 
TABLE 1. Performance characteristics of the 150-feature protein microarray.

\begin{tabular}{|c|c|c|c|c|}
\hline Analyte & Biological ED $\mathrm{ED}_{50}(\mathrm{pg} / \mathrm{mL})$ & Mean serum levels (pg/mL) & Array sensitivity $(\mathrm{pg} / \mathrm{mL})$ & ELISA sensitivity (pg/mL) \\
\hline ALCAM & na & 52000 & 100 & 24 \\
\hline ANG & na & 360000 & 10 & 6 \\
\hline $\mathrm{AR}$ & $5000-15000$ & 45.4 & 100 & na \\
\hline BDNF & $3000-10000$ & 27793 & 10 & 20 \\
\hline BLC & $5000-20000$ & na & 10 & na \\
\hline SVE-cadherin & na & 2800 & 1000 & 313 \\
\hline CCL28 & $400000-2000000$ & 43.8 & 30 & 2.58 \\
\hline SCD23 & na & $1.3 \mathrm{IU} / \mathrm{mL}$ & 10000 & $0.15 \mathrm{U} / \mathrm{mL}$ \\
\hline CD27 & na & na & 100 & na \\
\hline CD30 & $30000-100000$ & $6.4 \mathrm{U} / \mathrm{mL}$ & 10 & na \\
\hline CD40 & na & 102.1 & 300 & 15.6 \\
\hline CNTF & $50000-150000$ & nd & 300 & 8 \\
\hline CNTF R $\alpha$ & $200000-400000$ & na & 100 & na \\
\hline CT-1 & $1000-4000$ & 619.5 & 1000 & na \\
\hline CTACK & $100000-400000$ & 522 & 10 & 1.55 \\
\hline CTLA-4 & $2000000-4000000$ & nd & 1000 & 313 \\
\hline DR6 & na & na & 10 & na \\
\hline EGF & $100-400$ & 336 & 10 & 0.7 \\
\hline ENA-78 & $3000-15000$ & 1449 & 100 & 15 \\
\hline Eot & $10000-20000$ & 68.6 & 10 & 5 \\
\hline Eot-2 & $10000-50000$ & 249 & 10 & 1.83 \\
\hline Eot-3 & $250000-1000000$ & 9.7 & 100 & 2 \\
\hline Fas & $10000-40000$ & 9406 & 100 & 20 \\
\hline Fas ligand & $200000-500000$ & nd & 100 & 100 \\
\hline FGF acidic & $100000-300000$ & na & 10 & na \\
\hline FGF basic & $100000-250000$ & nd & 100 & 3 \\
\hline FGF-4 & $50-150$ & 93.8 & 300 & 30 \\
\hline FGF-6 & $100-300$ & na & 100 & na \\
\hline FGF-7 & $15000-25000$ & $<31.2$ & 10 & 15 \\
\hline FGF-9 & $1000-2000$ & na & 100 & na \\
\hline Flt-3 L & $500-1000$ & 93.9 & 10 & 7 \\
\hline Follistatin & $100000-400000$ & 2483 & 30 & 29 \\
\hline G-CSF & $20-60$ & 22 & 1000 & 20 \\
\hline GCP-2 & na & 156 & 100 & 1.6 \\
\hline GDNF & $1000-3000$ & na & 10 & na \\
\hline GM-CSF & $20-80$ & 1.72 & 10 & 3 \\
\hline Sgp130 & $3000-9000$ & 306000 & 100 & 80 \\
\hline GRO- $\alpha$ & $1000-4000$ & 93 & 10 & 10 \\
\hline GRO- $\beta$ & $3000-300000$ & na & 10 & na \\
\hline GRO- $\gamma$ & $10000-100000$ & na & 10 & na \\
\hline HB-EGF & $2000-5000$ & na & 100 & na \\
\hline HCC-1 & $200000-8000000$ & na & 30 & na \\
\hline $\mathrm{HCC} 4$ & $150000-750000$ & na & 100 & na \\
\hline HGF & $20000-40000$ & 721 & 100 & 40 \\
\hline HVEM & $500000-2000000$ & na & 30 & na \\
\hline ICAM-1 & na & 211000 & 10 & 350 \\
\hline ICAM-3 & na & 50000 & 100 & 580 \\
\hline IFN- $\alpha$ & $3.8 \times 10^{8} \mathrm{U} / \mathrm{mg}$ & $<10$ & 100 & 15.6 \\
\hline IFN- $\gamma$ & $800-1500$ & $<15.6$ & 10 & 8 \\
\hline IFN- $\omega$ & na & nd & 100 & 9.375 \\
\hline
\end{tabular}


Table 1. Continued.

\begin{tabular}{|c|c|c|c|c|}
\hline IGF-I & $1000-3000$ & 105000 & 100 & 26 \\
\hline IGF-IR & na & na & 100 & na \\
\hline IGF-II & $5000-10000$ & 29300 & 1000 & na \\
\hline IGFBP-1 & $1000000-4000000$ & 14300 & 30 & na \\
\hline IGFBP-2 & $30000-90000$ & 434200 & 100 & na \\
\hline IGFBP-3 & $50000-150000$ & 2375000 & 1000 & 50 \\
\hline IGFBP-4 & $30000-90000$ & na & 100 & na \\
\hline I-309 & $3000-9000$ & nd & 10 & 0.71 \\
\hline IL- $1 \alpha$ & $3.0-7.0$ & $<3.9$ & 10 & 1 \\
\hline IL- $1 \beta$ & $13-20$ & 0.536 & 10 & 1 \\
\hline IL-1r $\alpha$ & $20000-60000$ & 418 & 100 & 22 \\
\hline IL-1 sRI & $500000-1000000$ & na & 100 & na \\
\hline IL-1 sRII & $1000000-5000000$ & 11000 & 10 & 10 \\
\hline IL-2 & $250-500$ & 1.6 & 10 & 7 \\
\hline IL-2 R $\beta$ & $1000000-3000000$ & na & 300 & na \\
\hline IL-2 sRa & $500000-1000000$ & 1346 & 10 & 10 \\
\hline IL-2 R $\gamma$ & $3000000-6000000$ & na & 30 & na \\
\hline IL-3 & $100-400$ & $<31.2$ & 1000 & 7.4 \\
\hline IL-4 & $50-200$ & $<0.25$ & 10 & 10 \\
\hline IL-5 & $100-200$ & $<7.8$ & 10 & 3 \\
\hline IL-5 R $\alpha$ & $200000-300000$ & na & 100 & na \\
\hline IL-6 & $200-800$ & 1.62 & 10 & 0.7 \\
\hline IL-6 sR & $5000-15000$ & 31000 & 10 & 7 \\
\hline IL-7 & $200-500$ & 2.82 & 10 & 0.1 \\
\hline IL-8 & $100-500$ & 13.2 & 1 & 10 \\
\hline IL-9 & $500-1000$ & na & 1000 & na \\
\hline IL-10 & $500-1000$ & 2 & 10 & 3.9 \\
\hline IL-10 R $\beta$ & na & na & 10 & na \\
\hline IL-11 & $60-240$ & $<31.2$ & 100 & 8 \\
\hline IL-12 (p40) & $50-200$ & 77 & 10 & 15 \\
\hline IL-12 (p70) & $50-200$ & 1.93 & 10 & 0.5 \\
\hline IL-13 & $3000-6000$ & $<62.5$ & 10 & 32 \\
\hline IL-15 & $500-2000$ & 2.14 & 100 & 2 \\
\hline IL-16 & $2000000-10000000$ & 171 & 100 & 6.2 \\
\hline IL-17 & $2000-6000$ & $<31.2$ & 10 & 15 \\
\hline IL-18 & na & 126 & 100 & 12.5 \\
\hline IL-21 & $10000-40000$ & na & 300 & na \\
\hline IP-10 & $20000-60000$ & 89 & 10 & 1.7 \\
\hline I-TAC & $1000-5000$ & 177 & 10 & 13.9 \\
\hline Leptin/OB & $400-2000$ & $4760(\mathrm{M}), 20676(\mathrm{~F})$ & 3000 & 7.8 \\
\hline LIF & 500 & na & 100 & 8 \\
\hline SLIF-R $\alpha$ & $3000000-6000000$ & 4300 & 300 & 156 \\
\hline Lymphotactin & $50000-200000$ & na & 100 & na \\
\hline M-CSF & $500-1500$ & 670 & 10 & 9 \\
\hline M-CSF R & $4000-12000$ & na & 300 & na \\
\hline MCP-1 & $5000-20000$ & 370 & 10 & 5 \\
\hline MCP-2 & $30000-120000$ & 200 & 10 & na \\
\hline MCP-3 & $20000-80000$ & $<15.6$ & 10 & 2 \\
\hline MCP-4 & $200000-400000$ & na & 300 & na \\
\hline MDC & $3000-9000$ & 1089 & 10 & 62.5 \\
\hline MIF & $50000-100000$ & 1337 & 100 & na \\
\hline
\end{tabular}


Table 1. Continued.

\begin{tabular}{|c|c|c|c|c|}
\hline MIG & $200000-600000$ & 914 & 10 & na \\
\hline MIP- $1 \alpha$ & 2000-10 000 & $<46.9$ & 10 & 10 \\
\hline MIP- $1 \beta$ & $10000-30000$ & 80 & 10 & 11 \\
\hline MIP-1 $\delta$ & $2000-4000$ & na & 100 & na \\
\hline MIP-3 $\alpha$ & $500-2000$ & 26.3 & 30 & 0.47 \\
\hline MIP-3 $\beta$ & $100000-300000$ & na & 10 & na \\
\hline MMP-1 & na & 6490 & 300 & 52 \\
\hline MMP-2 & na & 1169000 & 300 & na \\
\hline MMP-7 & na & 2290 & 100 & 16 \\
\hline MMP-9 & na & 436000 & 300 & 156 \\
\hline MMP-10 & na & 770 & 100 & 4.13 \\
\hline MPIF & $200000-500000$ & 536 & 100 & 3.3 \\
\hline MSP & $10000-30000$ & $4 \mathrm{nM}$ & 100 & na \\
\hline NAP-2 & $100000-300000$ & na & 100 & na \\
\hline$\beta$-NGF & 800-1500 & 265 & 10 & na \\
\hline NT-3 & $10000-30000$ & 13.4 & 100 & na \\
\hline NT-4 & $5000-15000$ & na & 10 & na \\
\hline OSM & $150-300$ & $<15.6$ & 10 & na \\
\hline PARC & $500000-2000000$ & na & 100 & na \\
\hline PDGF-R $\alpha$ & $5000000-10000000$ & na & 3000 & na \\
\hline PECAM-1 & na & 20000 & 1000 & na \\
\hline PF4 & $5000000-15000000$ & 14700 & 300 & na \\
\hline PlGF & na & 18 & 10 & 7 \\
\hline Prolactin & $30-100$ & 9300 & 1000 & $7.6 \mathrm{mIU} / \mathrm{L}$ \\
\hline RANK & $4000-10000$ & na & 300 & na \\
\hline RANTES & $1000-5000$ & 49137 & 10 & 8 \\
\hline SCF & $2500-5000$ & 984 & 10 & 9 \\
\hline SCF R & $2000000-6000000$ & na & 100 & na \\
\hline SDF- $1 \alpha$ & 3000-9000 & 2000 & 10000 & 18 \\
\hline SDF- $1 \beta$ & $10000-30000$ & na & 10000 & na \\
\hline L-Selectin & na & 954000 & 10 & 300 \\
\hline $\mathrm{ST} 2$ & na & 500 & 30 & na \\
\hline TARC & $3000-9000$ & 331 & 100 & 5 \\
\hline TGF- $\alpha$ & $100-400$ & 22 & 100 & na \\
\hline TGF- $\beta 1$ & $20-60$ & 48600 & 10 & 7 \\
\hline TGF- $\beta 3$ & $10.0-30.0$ & 2400 & 10 & na \\
\hline TIMP-1 & $8 \mathrm{nM}$ & 190000 & 30 & 80 \\
\hline TIMP-2 & na & 106000 & 10 & na \\
\hline TNF- $\alpha$ & $20-50$ & 1.25 & 3 & 4.4 \\
\hline TNF- $\beta$ & $20-50$ & $<156$ & 10 & 16 \\
\hline TNF RI & $45000-90000$ & 1198 & 10 & 3 \\
\hline TNF-RII & $4000-16000$ & 1725 & 100 & 1 \\
\hline TRAIL & $4000-12000$ & nd & 5000 & 120 \\
\hline TRAIL R1 & $1000-3000$ & na & 10 & na \\
\hline TRAIL R4 & $30000-60000$ & na & 100 & na \\
\hline UPAR & $50000-150000$ & 2370 & 100 & 33 \\
\hline SVAP-1 & na & 125900 & 100 & 300 \\
\hline VEGF & $2000-6000$ & 220 & 10 & 9 \\
\hline VEGF-R2 & $4000-8000$ & 9768 & 1000 & 4.6 \\
\hline
\end{tabular}



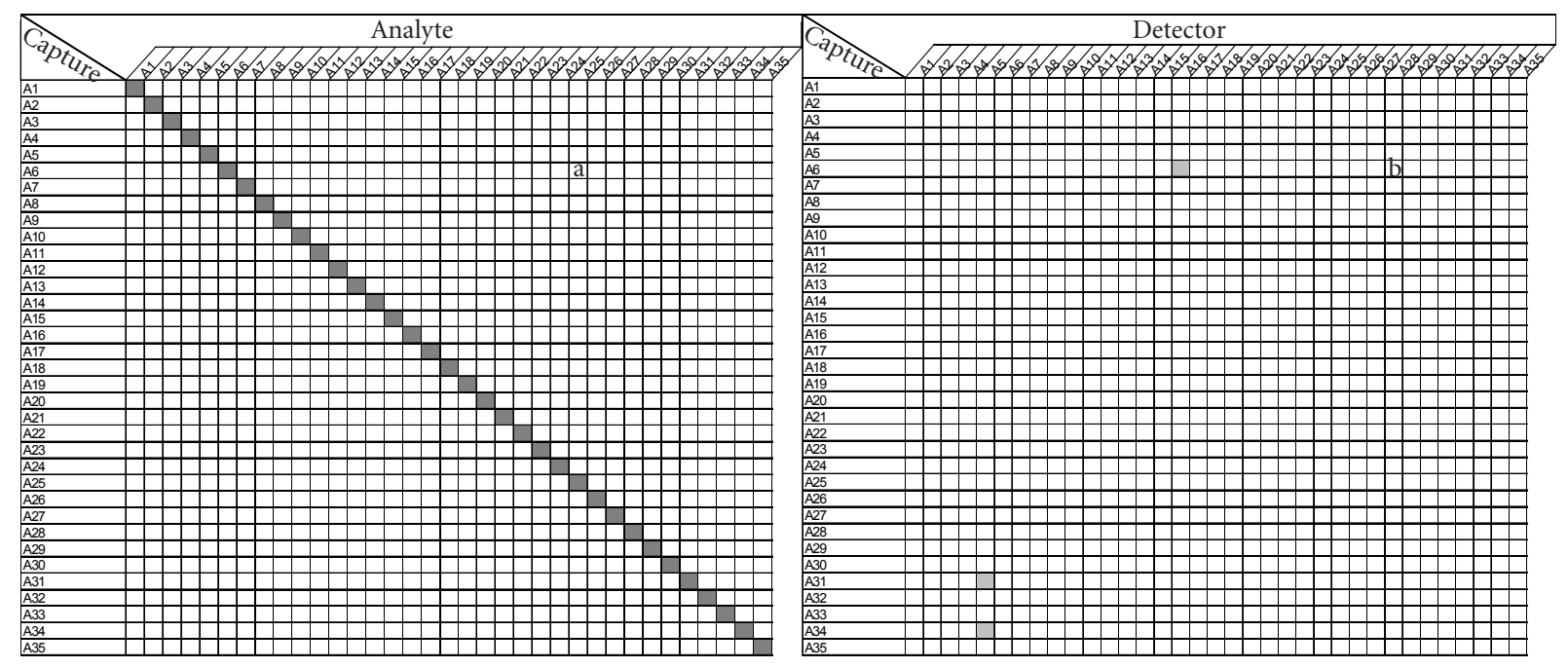

(A)

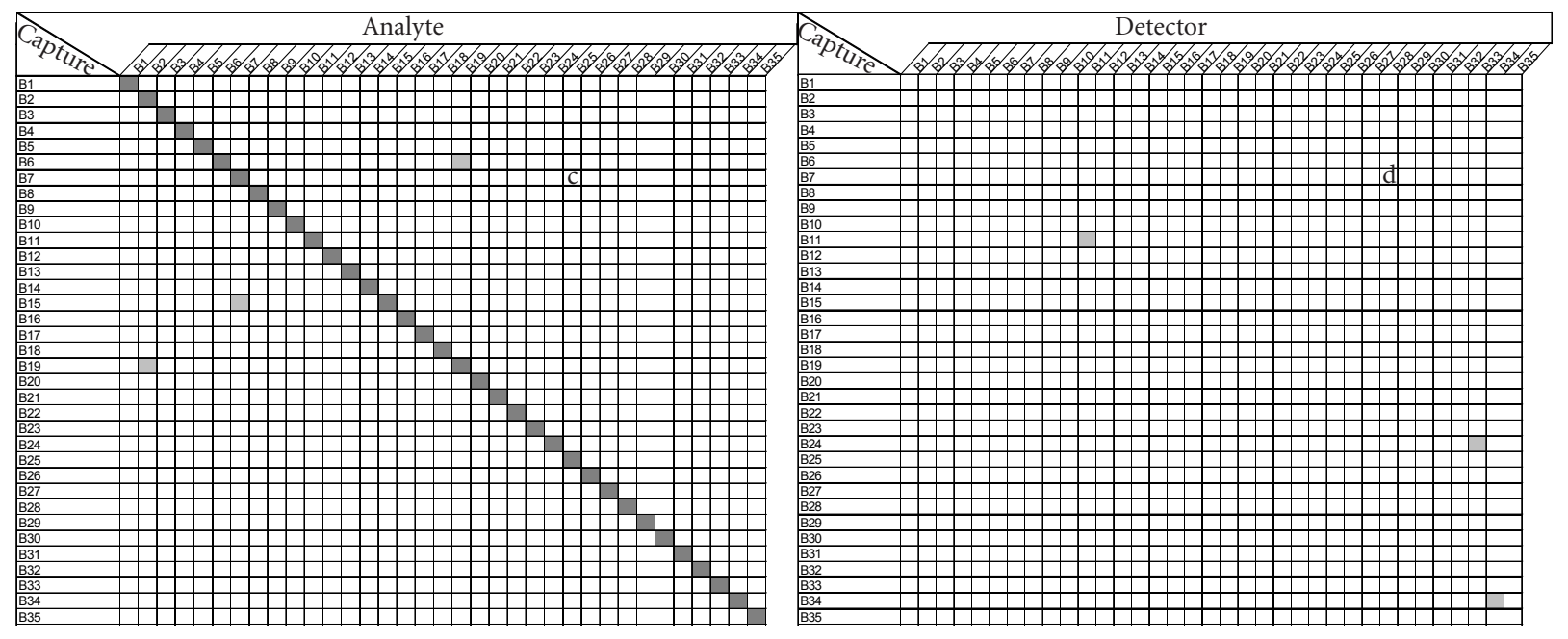

(B)

FIgURE 4. Cross-reactivity of capture antibodies and analytes ((a) and (c)), capture antibodies and detection antibodies ((b) and (d)) on the subarrays 3 (A) and 4 (B). Each subarray was printed with about 35 different capture antibodies (listed on the chart). Crossreactivity was determined by using different matched secondary antibody and $50 \mathrm{ng} / \mathrm{mL}$ or $0 \mathrm{ng} / \mathrm{mL}$ of its cognate analyte, which has been described in the text. A shaded square off the diagonal indicates the presence of nonspecific signals (intensity $\geq 300$ ). None of these nonspecific signals exceed the intensity of 600 fluorescence intensity units (images are scanned at PMT of 600 and power of $100 \%$ on Axon scanner).

The analytical sensitivity of the microarray immunoassay was determined by using serial dilutions of each single purified antigen. The sensitivity of detection, defined as the lowest concentration that delivered clear specific signal intensity above detection threshold (mean intensity of the negative control plus $2 \mathrm{SD}$ ), was calculated. Sixty-five (43\%) of the 150 cytokine features had a sensitivity of $\leq 10 \mathrm{pg} / \mathrm{mL}, 52(35 \%)$ had a sensitivity of $\leq$ $100 \mathrm{pg} / \mathrm{mL}, 27(18 \%)$ had a sensitivity of $\leq 1000 \mathrm{pg} / \mathrm{mL}$, and $6(4 \%)$ had a sensitivity of $\geq 1,000 \mathrm{pg} / \mathrm{mL}$ (Table 1 ). Sixty-two of the cytokines represented on the chip are unique, with no corresponding commercially available ELISA kits. The sensitivity goal for these arrays was adequacy to detect biologically relevant (ie, 2-fold) increases in cytokine level above normal values in clinical fluids including serum and plasma.

\section{Specificity of antibody microarray}

Although antibodies are highly specific for their respective cognate proteins, it is possible that structurally related proteins might have similar epitopes. Crossreactivity or nonspecific signals between immobilized 


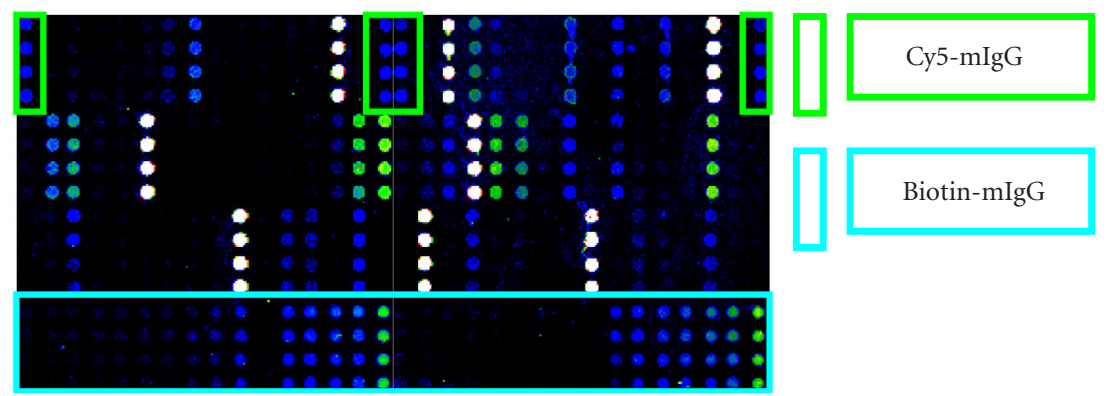

(a)

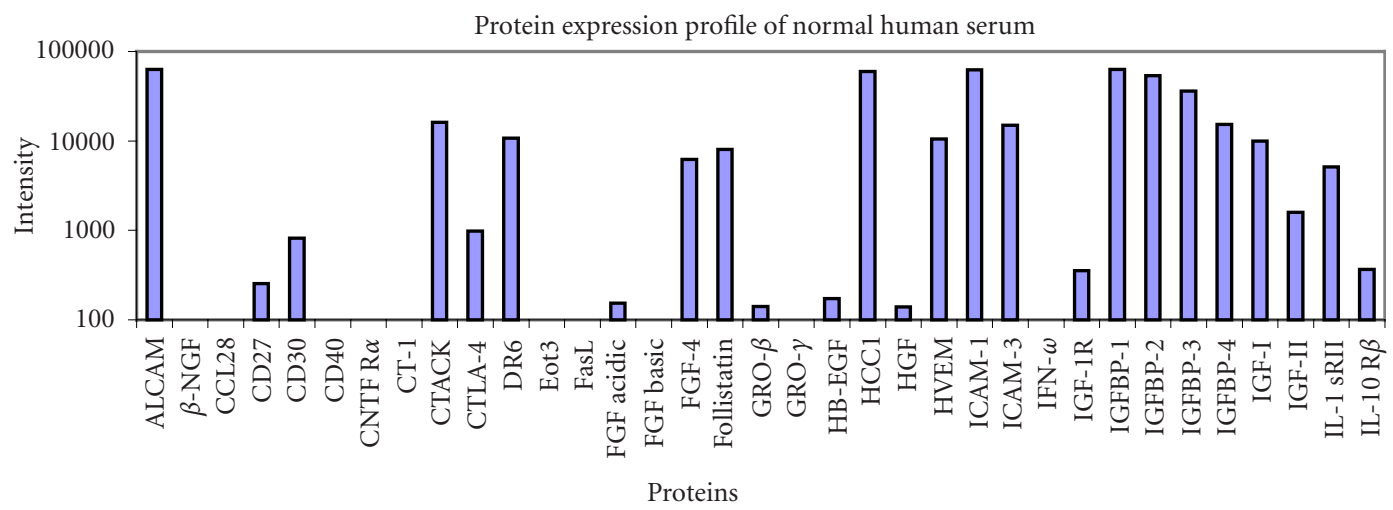

Protein expression profile of normal human serum

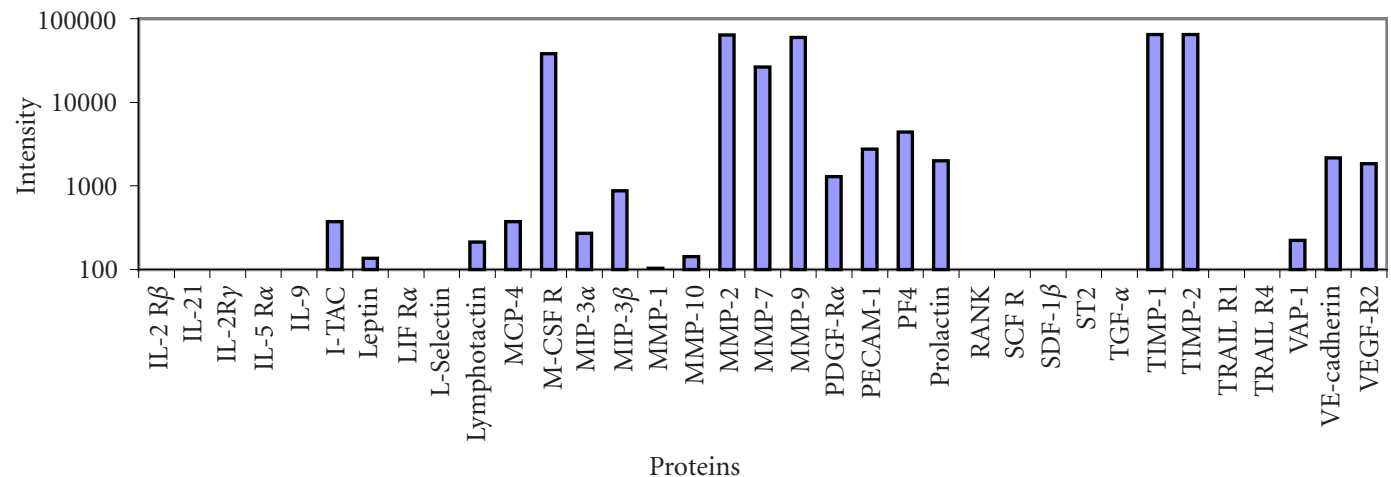

(b)

FIGURE 5. Protein expression profiling of normal human serum (Sigma) on 70-feature antibody microarray. Specific signals detected were consistent with the protein level in serum. (a) Images of detecting 70 proteins in antibody microarray obtained with Axon microarray scanner. (b) Fluorescence intensities were derived from microarray images with averaging four spots of the same feature.

capture antibodies and antigens or detection antibodies for 150 features were determined in three different ways. First, the cross-reactivity of individual antigens or detection antibodies was determined by analyzing a single antigen at 0 and $50 \mathrm{ng} / \mathrm{mL}$ with its corresponding paired detection antibody. Any signals on the $0 \mathrm{ng} / \mathrm{mL}$ array were categorized as cross-reactivity between the detection and capture antibodies. With $50 \mathrm{ng} / \mathrm{mL}$ analyte, signals should have only been observed at the specific locations. Other signals after background subtraction (the $0 \mathrm{ng} / \mathrm{mL}$ array) were assumed to be cross-reactivity from the analyte.
Nonspecific signals were eliminated by segregating all features into multiple subarrays, thus the capture antibodies producing nonspecific signals were physically separated from those particular detection antibodies or antigens. This also allowed simultaneous detection of both components of a biological signaling system, such as a growth factor and its receptor.

Residual cross-reactivity and nonspecific signals were first minimized by optimization of washing and blocking conditions [4]. Next, a mixture of several analytes at concentrations of $10 \mathrm{ng} / \mathrm{mL}$ each was applied to the chip, 
followed by detection with the complete detection antibody cocktail. Signals were only observed where both the analyte and its specific detection antibody were present. Then a mixture of all analytes in the subarray at $10 \mathrm{ng} / \mathrm{mL}$ each was added to the microarray, but detection was with an incomplete cocktail of antibodies. Signals were only detected on those features corresponding to the specific detection antibodies added. As shown in Figure 4, both cross-reactivity between capture antibodies and analytes and cross-reactivity between capture antibodies and detection antibodies in each subarray were minimized. Approximately $99 \%$ of nonspecific binding pairs had fluorescence intensity units of less than 300 , used as the background signal minimum during the data quantitation. Interferences from biological specimen were screened using normal human serum and single detectors (biotinylated detection antibody) corresponding to each feature on the chip. Only specific signals of the proteins present in the specimen were detected by their associated detector antibody. Other nonspecific signals or background signals were negligible.

\section{Validation of the antibody microarray}

The antibody microarray was validated by running assays with normal human serum (Sigma, St. Louis, Mo) on our 70-feature protein chip. We simultaneously detected 70 proteins in normal human serum. Signals corresponding to specific proteins were identified (Figure 5), which are consistent with their presence with significant level in the normal human serum (Table 1). Proteins with low fluorescence signal intensities agree with their very low level in serum (if present), indicating that our antibody microarray provides a specific, robust, and high-throughput approach for global analysis of protein expression.

\section{CONCLUSION}

Immunoassays on microarrays hold appeal for studies requiring the ability to quantify many selected proteins simultaneously. Considerable progress has been made in this area recently in terms of increased assay sensitivity and complexity (ie, degree of multiplexing). Rolling-circle amplification facilitates the use of such arrays with its powerful degree of signal enhancement and simultaneous detection of a large number of defined analytes. Such robust systems will enable routine use of antibody arrays in both research and diagnostic modalities.

\section{REFERENCES}

[1] MacBeath G, Schreiber SL. Printing proteins as microarrays for high-throughput function determination. Science. 2000;289(5485):1760-1763.

[2] Zhu H, Bilgin M, Bangham R, et al. Global analysis of protein activities using proteome chips. Science. 2001;293(5537):2101-2105.

[3] Haab BB, Dunham MJ, Brown PO. Protein microarrays for highly parallel detection and quantitation of specific proteins and antibodies in complex solutions. Genome Biol. 2001;2(2):1-13.

[4] Schweitzer B, Roberts S, Grimwade B, et al. Multiplexed protein profiling on microarrays by rollingcircle amplification. Nat Biotechnol. 2002;20(4):359365.

[5] Petricoin EF 3rd, Ardekani AM, Hitt BA, et al. Use of proteomic patterns in serum to identify ovarian cancer. Lancet. 2002;359(9306):572-577.

[6] Huang RP, Huang R, Fan Y, Lin Y. Simultaneous detection of multiple cytokines from conditioned media and patient's sera by an antibody-based protein array system. Anal Biochem. 2001;294(1):55-62.

[7] Wiese R, Belosludtsev Y, Powdrill T, Thompson P, Hogan M. Simultaneous multianalyte ELISA performed on a microarray platform. Clin Chem. 2001;47(8):1451-1457.

[8] Lizardi PM, Huang X, Zhu Z, Bray-Ward P, Thomas DC, Ward DC. Mutation detection and singlemolecule counting using isothermal rolling circle amplification. Nat Genet. 1998;19(3):225-232.

[9] Schweitzer B, Wiltshire S, Lambert J, et al. Immunoassays with rolling circle DNA amplification: a versatile platform for ultrasensitive antigen detection. Proc Natl Acad Sci USA. 2000;97(18):1011310119.

[10] Falipou S, Chovelon JM, Martelet C, Margonari J, Cathignol D. New use of cyanosilane coupling agent for direct binding of antibodies to silica supports. Physicochemical characterization of molecularly bioengineered layers. Bioconjug Chem. 1999;10(3):346-353.

[11] Nallur G, Luo C, Fang L, et al. Signal amplification by rolling circle amplification on DNA microarrays. Nucleic Acids Res. 2001;29(23):e118.

\footnotetext{
* Corresponding author.

E-mail: weipings@molecularstaging.com Fax: + 1203776 5278; Tel: + 12037725054
} 

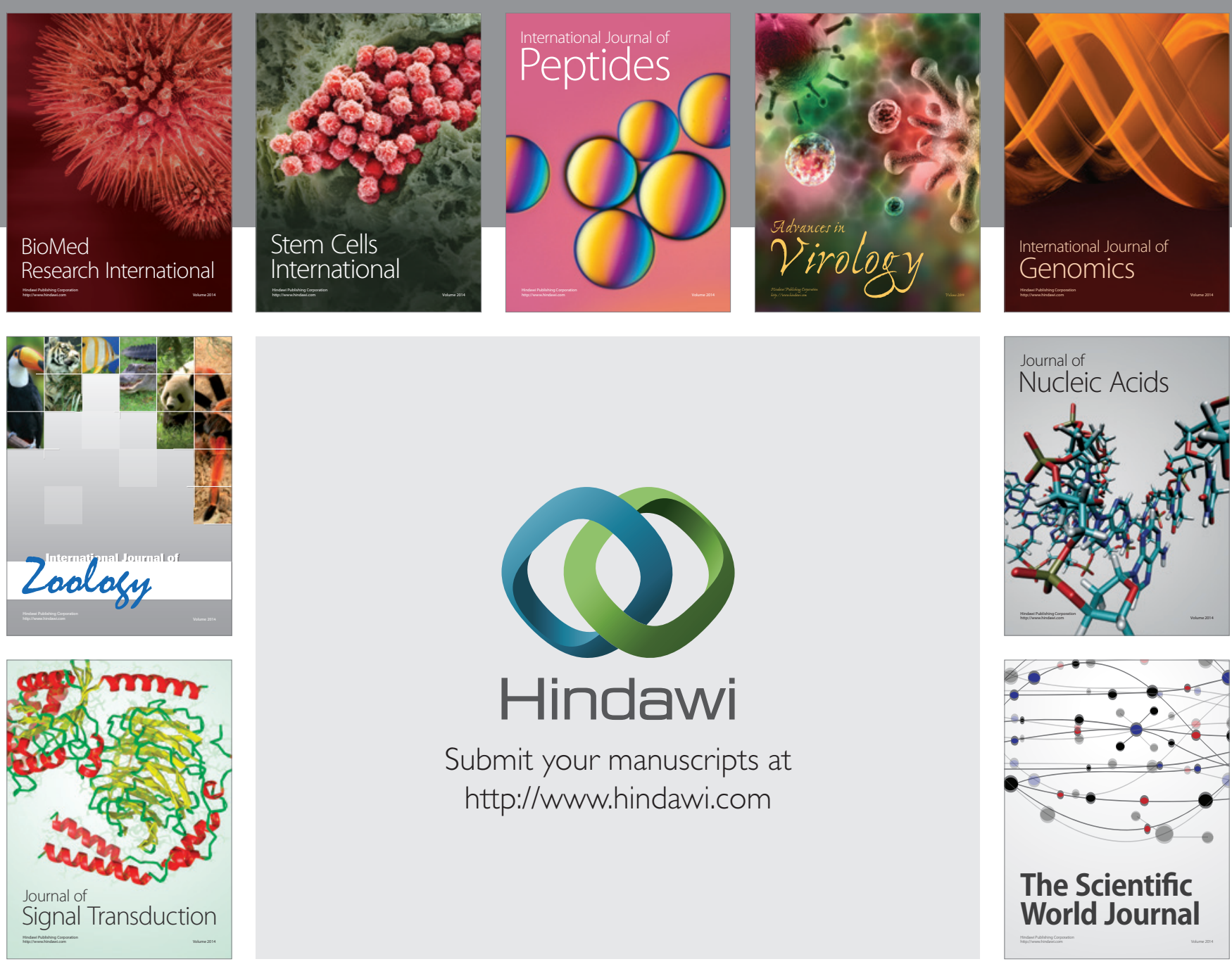

Submit your manuscripts at

http://www.hindawi.com
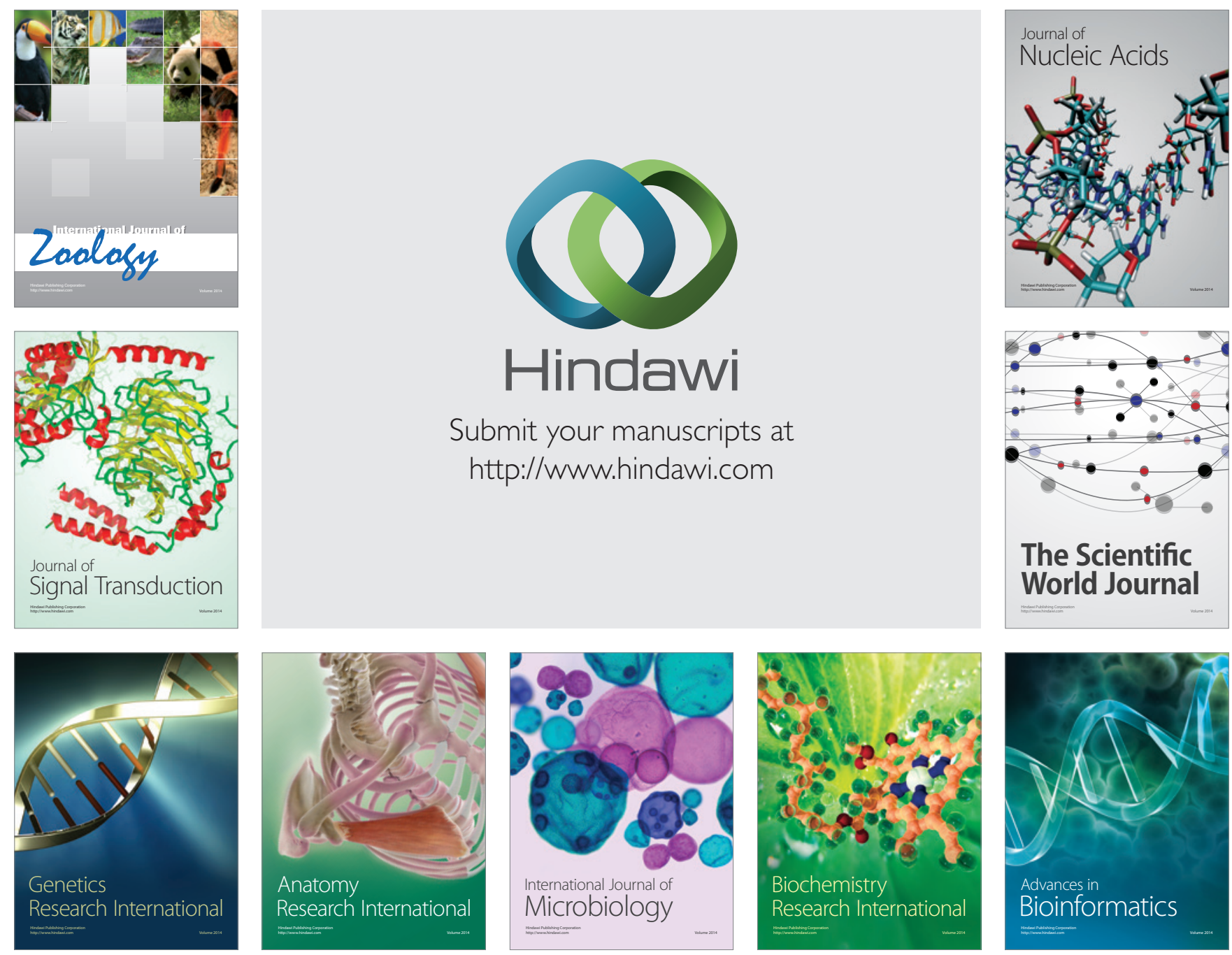

The Scientific World Journal
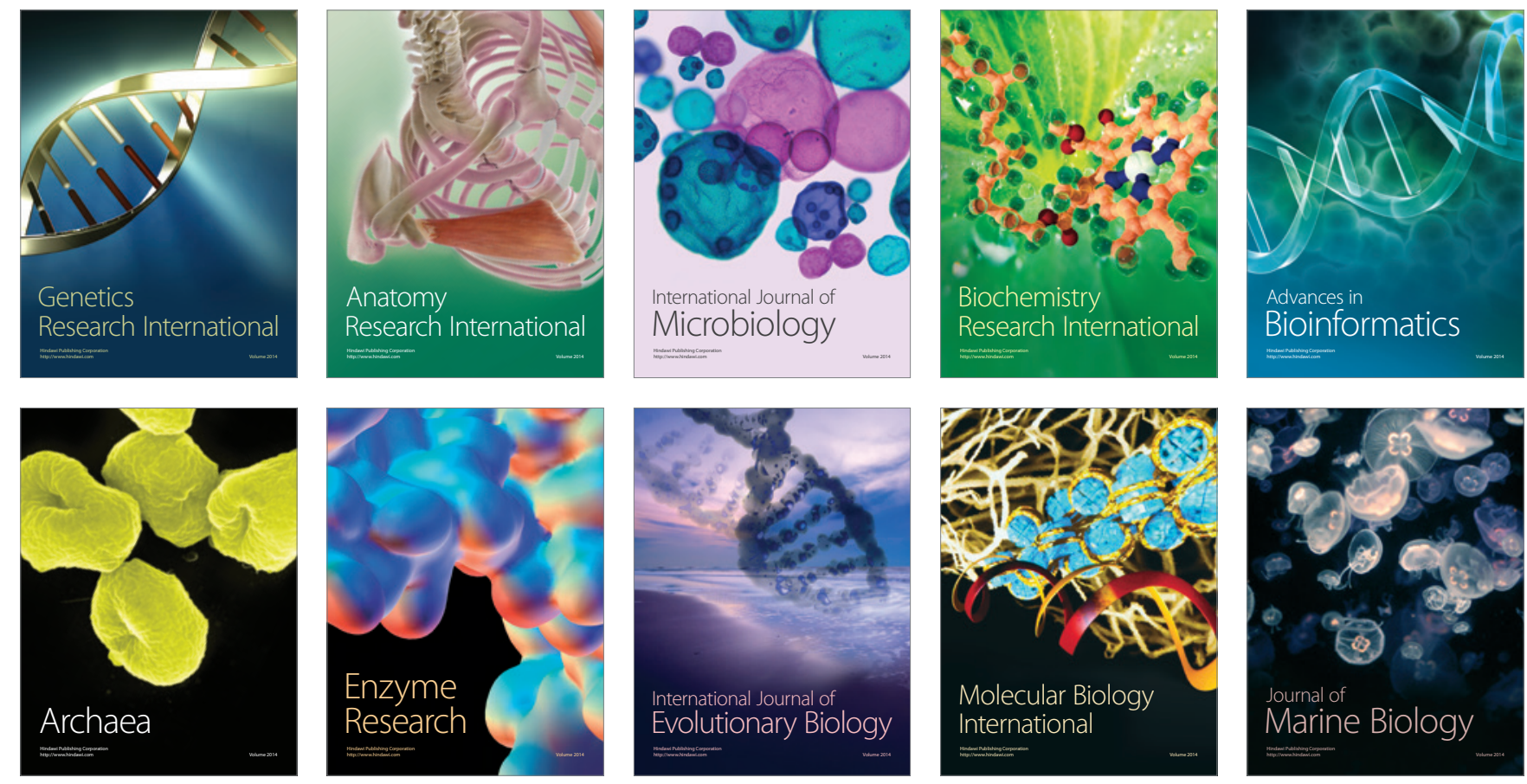